\title{
Possibilities of ultrasonography in diagnosing causes of dyspnea in palliative care cancer patients
}

\begin{abstract}
Dyspnea is an ailment which is relatively frequently reported by cancer patients, and it can be difficult to determine the cause of the symptom at home hospice. Thanks to the application of mobile ultrasound scanner, the physician can often determine the cause of dyspnea during a home visit, which makes it unnecessary to carry out diagnostic procedures at the hospital. The article presents two cases of female patients in whom the application of at-home ultrasound proved to be useful in determining the cause of dyspnea. The first patient was diagnosed with pericardial tamponade at home - pericardial cavity puncture was performed at the hospital — while in the case of the second patient, pneumonia was both diagnosed and monitored at home with the use of ultrasonography.
\end{abstract}

Palliat Med Pract 2020; 14, 3: 205-211

Key words: lung ultrasound, point-of-care ultrasonography, palliative care, dyspnea

\section{Introduction}

The point-of-care ultrasonography (POCUS) has been used clinically for a dozen or so years, mostly at intensive care units and emergency wards [1]. There are many simple diagnostic algorithms targeted at diagnosing and differentiating basic pathologies, e.g. protocols such as FAST (Focused Assessment with Sonography for Trauma), EFAST (Extended Focused Assessment with Sonography for Trauma), FEEL (Focused Echocardiographic Evaluation in Life Support), FATE (Focus Assessment Transthoracic in Emergency), BLUE (Bedside Lung Ultrasound in Emergency), RUSH (Rapid Ultrasound in Shock and Hypotension). In principle, the examination is to be performed by a clinician who takes direct care of the patient, and it is to be performed at the patient's bedside - not at at a diagnostic laboratory. The availability of mo- bile, often miniaturised, damage-resistant ultrasound scanners makes it possible to conduct basic ultrasound examinations at any points of care.

The possibility of applying point-of-carte ultrasonography in patients under the care of home hospices seems attractive. Reliable differential diagnosis of many diseases and symptoms, including dyspnea, can be conducted during a home visit, with the examination being particularly focused on the presence of potentially reversible causes. It is not necessary to transport the patient to the hospital and the examination is conducted in conditions which provide the patient with maximum comfort. Two cases of patients in whom the application of ultrasonography at home proved to be useful in the determination of the cause of dyspnea.

\footnotetext{
Address for correspondence:

Jolanta Cylwik

Anesthesiology and Intensive Care Unit, Masovian Voivodeship Hospital in Siedlce

e-mail: jolacylwik@o2.pl
} 


\section{Case 1}

A 58-year-old patient with arterial hypertension undergoing palliative radiotherapy for lung cancer with bone and CNS metastases. Patient's well-being was deteriorating for several days. Her husband asked for an urgent visit of the hospice doctor due to increasing dyspnea - initially exertional, then at rest. During physical examination, the patient was conscious, Glascow Coma Score (GCS) 15 points. Increased dyspnea at rest - approximately 40 breaths per minute, increased breating efforts. $\mathrm{SaO}_{2} 90 \%$. Bilateral, parabasal crackles on ausculation. Blood pressure $85 / 60 \mathrm{~mm} \mathrm{Hg}$, heart rate 140/per minute. Symmetrical swelling of shanks. Body temperature 36.4 degrees Celsius, glycaemia 100 mg\%. Ultrasound lung evaluation showed bilateral A-line artifacts and preserved lung sliding and single B-line artifacts. Multiple B-line artifacts, were visible parabasally and bilaterally confluent into a whitelung image (Fig. 1).

No inflammatory consolidations or pleural fluid were visible. The POCUS examination was continued - heart evaluation. A large volume of pericardial effusion, haemodynamically significant, was visible in substernal projection (Fig. 2).

Based on the history, physical examination and ultrasound the patient was diagnosed with pericardial tamponade. She was urgently referred to the cardiology ward, where a puncture was performed and approximately $600 \mathrm{ml}$ of bloody fluid was decompressed. Dyspnea subsided completely.

The addition of ultrasonography to clinical examination made it possible to conduct differential diagnostics in the described patient and establish the diagnosis. It would not be possible without a simple, at-home ultrasound examination. The administered

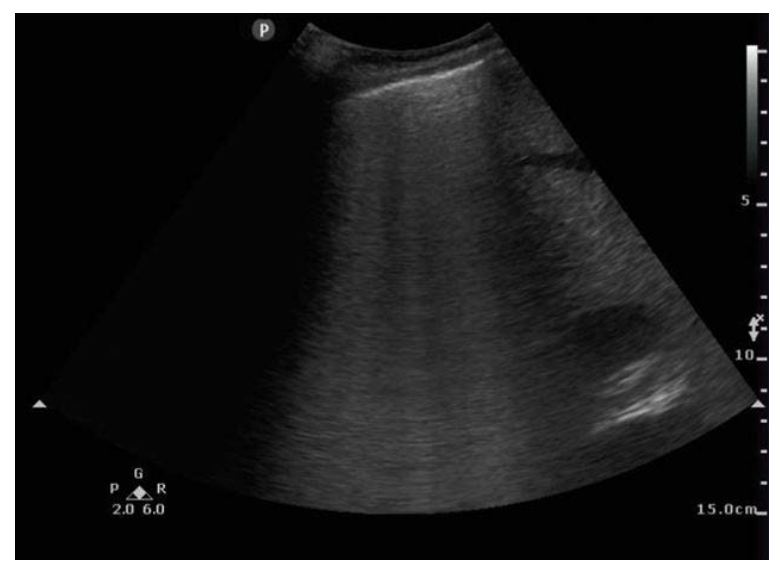

Figure 1. Ultrasound examination of lungs. Image of the interstitial-alveolar syndrome, white-out lung. Confluent B-line artifacts. A-line artifacts not visible treatment was oriented at the cause of the symptom, thanks to which dyspnea subsided.

\section{Case 2}

A 78-years-old patient diagnosed with colorectal cancer with metastases to the liver. Causal treatment ended, the patient was under the care of a home hospice for 4 weeks. Patient with chronic heart failure, hypertension, ischaemic heart disease. For several days, she was reporting deteriorating well-being, fatigue, and since the day before - fever of up to 39 degrees Celsius. Dyspnea increased since morning, patient's family asked for a visit of hospice doctor.

In physical examination, resting respiratory rate approximately 18 breaths per minute, minimal effort causes increased dyspnea. $\mathrm{SaO}_{2} 90 \%$. On ausculation, diffuse rales on the left, from the angle of the shoulder blade. Cardiovascular system efficient - blood pressure 150/90 mm Hg, heart rate 100 per minute. Body temperature 38.4 degrees Celsius, glycaemia $180 \mathrm{mg} \%$.

The ultrasound examination began with an evaluation of sites where abnormalities were observed in physical examination - the left side of the chest. The examination revealed numerous, minor subpleural consolidations and sectionally visible layer of pleural effusion -image of pneumonia - in the central and lower field (Fig. 3).

The initial diagnosis was confirmed by an ultrasound examination conducted at patient's home. Treatment, the efficiency of which was monitored with subsequent ultrasounds, was implemented.

\section{Discussion}

Dyspnea is a frequent symptom reported by patients suffering from cancer, and it occurs in $48-69 \%$

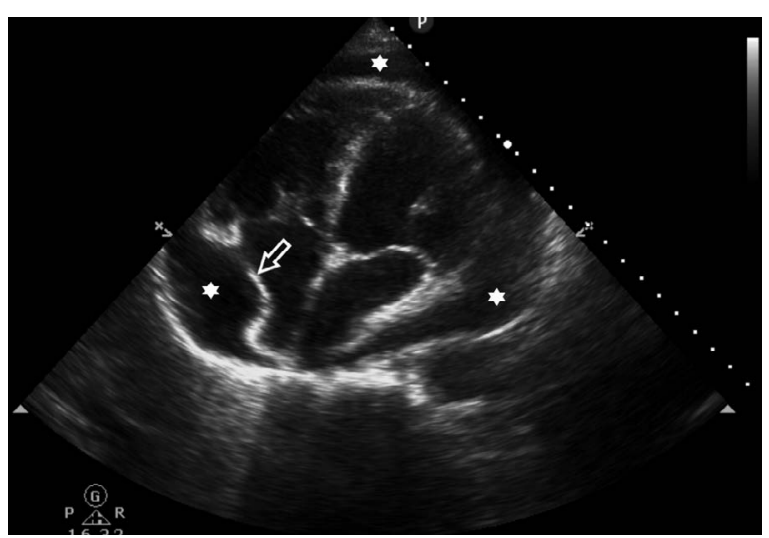

Figure 2. Substernal projection. Effusion in the pericardial sac $\left(^{*}\right)$. The arrow marks the right atrial wall collapsing during systole 


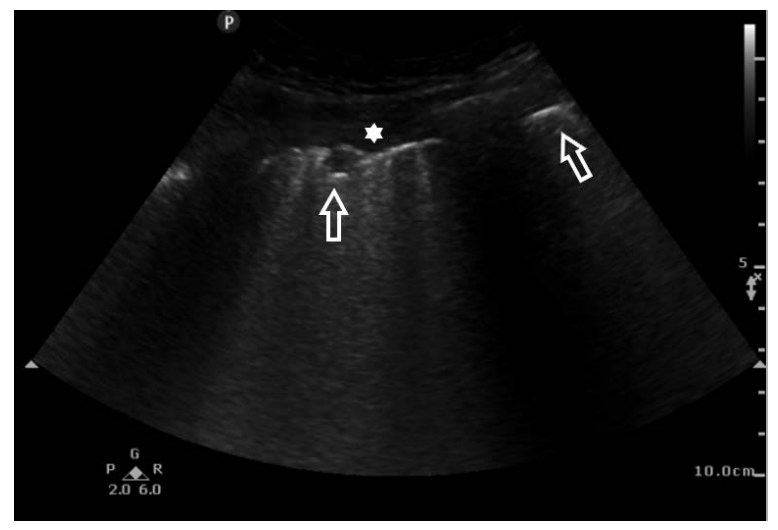

Figure 3. Ultrasound examination of lungs - numerous, minor subpleural consolidations in the lower area of the left lung $(\downarrow)$, sectionally visible layer of reactive fluid in the pleura $\left({ }^{*}\right)$

of them, regardless of the location of the primary focus, and in $80 \%$ of patients with lung cancer [2]. Dyspnea is a complex symptom - according to the "total dyspnea" concept, the way and intensity with which dyspnea is experienced are affected by various factors which comprise the physical, mental, social and spiritual components [3]. As for medical causes, the pathology may result from the presence of tumor: obstruction of airways caused by the presence of pathological mass, primary and secondary infiltrations of the tumor onto pulmonary tissue, superior vena cava syndrome, pleural infiltration, pleural effusion, pericardial effusion, abdominal dropsy. Other causes are associated with the presence of the neoplasm - cachexia, pulmonary embolism, paraneoplastic syndromes, pneumonia. The occurrence of dyspnea may be related to causes associated with the consequences of antineoplastic therapy, both chemical treatment (pulmonary fibrosis, eosinophilic pneumonia, bleeding into alveoli) and radiotherapy (radiation pneumonia, pulmonary fibrosis, pericarditis). Sometimes, dyspnea may be caused the presence and severity of comorbidities: COPD, bronchial asthma, heart failure, interstitial lung diseases, neuromuscular diseases, obesity, thoracic deformities [2]. Some of the above causes are potentially reversible.

\section{Point-of-care lung ultrasound}

During a home visit to a patient with dyspnea who is under the care of home hospice, the doctor tries to determine the cause of dyspnea on the basis of the history taken and the physical examination. Pulse oximetry is an additional examination which can be performed. For obvious reasons, other diagnostic examinations - laboratory and traditional imaging - frequently cannot be performed at home. Remem- bering that there are usually several coexisting causes of dyspnea in patients with advanced cancer, and at least one of these causes is usually reversible [3], the diagnostic possibilities provided by basic ultrasound examination can be of substantial value.

Imagining diagnostics during a home visit meets the basic assumptions of point-of-care ultrasound examination. A simple ultrasound devices with basic functions is entirely sufficient for the performance of an at-home ultrasound examination. There is a tendency to create examination protocols in such a way that the entirety of basic diagnostics can be performed with the use of one probe - usually of convex type (standard head for the examination of the abdominal cavity) with a frequency of 3.5-5.0 MHz [4]. The probe can be used to examine both thoracic (heart, lungs) and abdominal organs. If the physician has an additional linear probe, the examination can be extended to evaluate deep veins of lower limbs and to perform detailed examination of the lungs. Ultrasound examination aimed at detecting the cause of dyspnea can be performed in basically every position - lying down, sitting or standing up, depending on the needs and abilities of the patient.

The BLUE (Bedside Lung Ultrasonography in Emergency) protocol, differentiating basic pulmonary pathologies based on ultrasound examination, is an internationally recognised diagnostic algorithm. Knowledge thereof is mandatory for physicians beginning work in accordance with POCUS. This article presents the main assumptions and diagnostic possibilities of ultrasound examination performed at patient's home, therefore, the protocol will not be discussed in detail.

Ultrasound diagnostics of lungs was developing in stages [4], and in 2012 a consensus on lung ultrasonography was reached [5]. A significant advantage of lung evaluation is the easiness of obtaining diagnostically good images - the interpretation of the obtained scans is more difficult. Such method is based on the assessment of physical artifacts which are formed at the borderline between the pleura and lung parenchyma (the air in the alveoli prevents the ultrasound beam from spreading deep into the lungs). It is, therefore, obvious that it is only possible to visualise pathologies which are in direct contact with the pleura - if a pathological lesion is located in the deeper layers, the air between the lesion and the chest wall will prevent its visualisation [6].

Ultrasound examination in palliative medicine has numerous advantages, such as the possibility of performing the examination at patient's home, the fact that is is not necessary to position the patient in a special way, lack of pain, lack of ionising radiation and the possibility to repeat the examination. Moreover, 


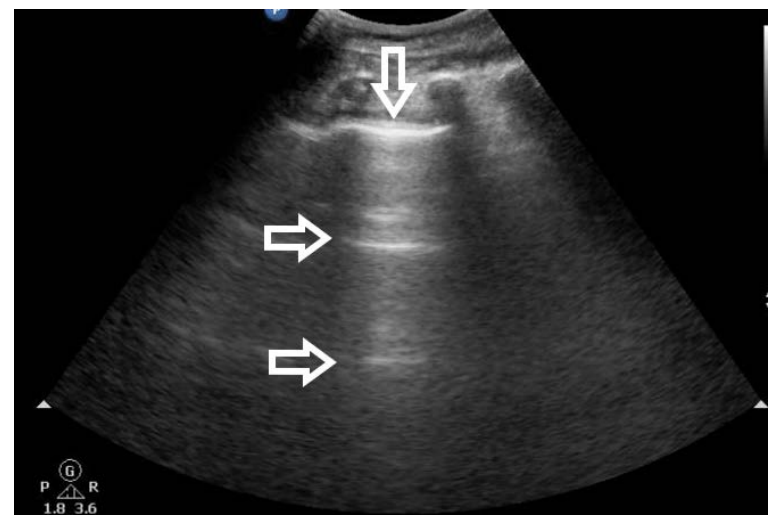

Figure 4. Normal ultrasound image of lungs. Pleural line $(\downarrow)$, arrangement of A-line artifacts $(\rightarrow)$

ultrasound examination makes it possible to quickly differentiate between inflammatory lesions associated with the progress of cancer, pulmonary oedema and the presence of fluid in the pleural cavity [7].

The examination is performed by moving the head, placed across the intercostal spaces, over the anterior, lateral and posterior surface of the chest. An exploratory examination aimed at evaluating the entire lungs in detail can be performed by assessing 3 symmetrical points at both sides of the chest on the anterior and posterior surface [8].

An artifact which is present in a normal image of lungs are A-lines - hyperechogenic lines, parallel to the pleura, regularly repeating in the ultrasound image at intervals consistent with the distance between the surface of the chest wall and the pleural line (reverberation artifact). If the $A$-line artifact coexists with lung sliding (visible relative movement of pleural plaques, consistent with the respiratory rhythm) - the image indicates a properly ventilated lung [7] (Fig. 4).

In the case of heart failure, excess accumulation of fluid occurs, at first interlobularly, and with an increase in its amount interstitial alveolar syndromes occur. Presence of extravascular fluid causes the occurrence of characteristic B-line artifacts in ultrasound imagining. The artifacts are vertical, hyperechogenic lines, laser-like, starting at the pleural line and running to the lower edge of the screen, regardless of the imaging depth set (Fig. 5).

Presence of two B-lines in a single diagnostic window is considered to be normal, especially in lower-posterior parts of the lungs. If 3 or more lines are visible, it indicates pathology [9]. The number of B-line artifacts correlates well with patient's clinical condition and the severity of heart failure in accordance with the NYHA classification [10-14]. Ultrasound image confirming the presence of the interstitial syndrome has been deemed to be unambiguous and entitling to

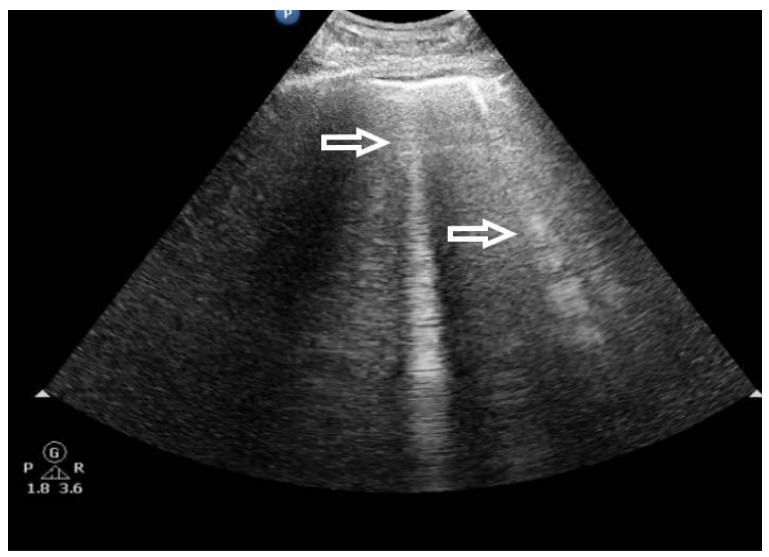

Figure 5. Transthoracic lung evaluation. Presence of multiple B-lines $(\rightarrow)$ indicates interstitial-alveolar syndrome

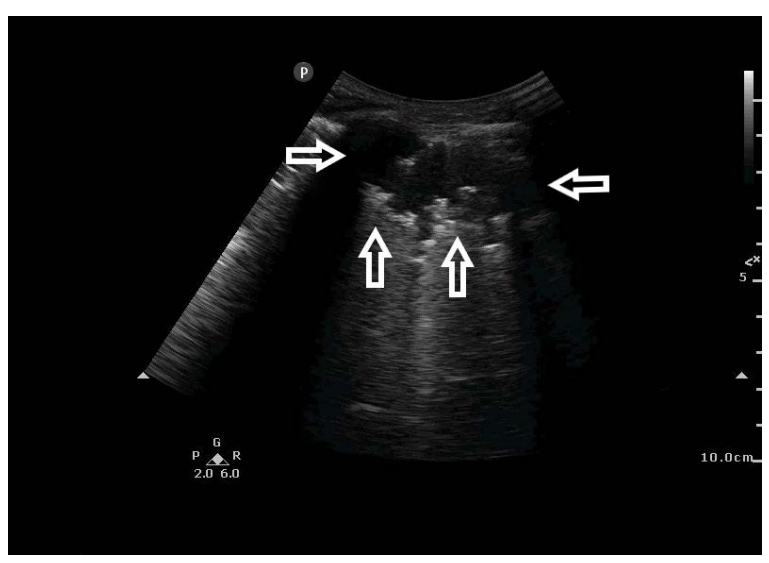

Figure 6. Ultrasound examination of lungs. Subpleural inflammatory consolidation (surrounded by arrows) Visible symptom of hepatisation, shred sign and fluid bronchogram

distinguish cardiological oedema from exacerbation of COPD or other pathology [5, 13].

Apart from oedematous lesions, lung ultrasound provides the possibility of identifying the presence of inflammatory consolidations. An area affected by the inflammatory process is consolidated, which results in the occurrence of "hepatisation of lungs". Echogeneity of pulmonary tissue becomes comparable to that of the liver. The "shred sign", which consists in the smooth borderline of the lung becoming jugged, irregular and smudged, occurs. In addition, air bronchogram (air in the bronchial tree within the consolidation) and fluid bronchogram are visible [15, 16] (Fig. 6).

Apart from the inflammatory changes or changes associated with heart failure, pleural effusion may be the cause of dyspnea in patients on palliative care. Its location, rate of accumulation and increased severity of symptoms related thereto are very different. The- 
refore, a simple and sensitive examination, such as ultrasonography, can be very helpful in determining the location, assessing the volume of the fluid and, in particular, determining the site of pleural cavity puncture.

Pleural cavity puncture is a procedure associated with the risk of pneumothorax. The complication can be detected in ultrasound examination with very high specificity and sensitivity: elimination of the pleural lung sliding, presence of A-line artifact, complete lack of B-line, presence of lung point and, additionally, in the M-mode option, presence of the stratosphere sign [17].

\section{Point-of-care heart ultrasound}

After performing the ultrasound examination of the lungs, regardless of the result thereof, that is regardless of whether the potential cause of dyspnea was or was not found, the next step should be basic assessment of the heart. Pathologies caused by diseases of heart, pericardium or pulmonary circulation may constitute the cause of increased dyspnea in patients on palliative care. The examination should be targeted at identifying key pathologies, and the physician conducting it should attempt to answer the following questions [18]:

1. Is fluid that may cause tamponade present in the pericardial sac?

2. What is the global myocardial contractility?

3. Is the ratio of the left heart ventricle to the right heart ventricle normal (possibility of massive pulmonary embolism)?

Traditional substernal projection with the use of liver as an acoustic window usually suffices for the performance of basic assessment. The convex-type head should be placed below the xiphoid process at the angle of approximately 15 degrees to the anterior chest wall. The projection makes it possible to visualise well the pericardium and the right ventricle well. Key diagnostic elements can be assessed even in technically difficult conditions.

The first element that attention should be paid to is the presence of fluid separating the pericardium layers. If fluid is present, and it additionally impacts the heamodynamics of the low-pressure right ventricle and right atrium, it can be assumed that tamponade is the cause of dyspnea $[19,20]$.

The estimation of the global contractility of the heart muscle should comprise an evaluation of the shortening of walls, left and right ventricle, as well as the contractility of the interventricular septum. The assessment of fraction is performed by estimating it as either good or low [21]. If the contractility is overall weak with associated widening of heart cavities, it can be assumed that the patient is suffering from low output syndrome and dyspnea related thereto. If numerous B-lines are additionally visualised in lung examination, the diagnosis is certain.

As already mentioned, the proportion of the size of the left ventricle to the size of the right ventricle should be determined in basic echocardiographic examination. In normal conditions the ratio is 1:0.6 [22]. Regardless of the cause, an increase in pulmonary circulation pressure causes widening of the right ventricle and atrial cavity. Pulmonary embolism, which is a frequent complication of cancer, constitutes a classic example. In the case of acute, massive embolism, the widening of the lumen of the right ventricle will be significant and will dominate over the left ventricle in size. In pulmonary hypertension we can also observe pathological movement of the interventricular septum, both in diastole and systole. Pulmonary hypertension is also characterised by the formation of the heart apex by the right, not left - as its in normal conditions - ventricle (the McConnel's sign has high positive predictive value for pulmonary embolism) [23]. Conclusions that can be drawn from the answers to the three most important questions above can certainly affect the further direction of treatment applied in patients with dyspnea.

Discussing the possibilities of fast, bedside ultrasound diagnosis in patients suffering from dyspnea, we should emphasise that the examination makes it possible to identify pathologies outside the thorax, which may cause or increase dyspnea [24]. The examination for the presence of free fluid in the abdominal cavity, which is a frequent symptom in patients suffering from cancer, constitutes an example of differential diagnosis. If abdominal dropsy is massive and causes intra-abdominal hypertension syndrome, it may constitute the cause of dyspnea. The assessment of peritoneal fluid is fairly simple. The FAST protocol may be helpful -4 applications of the head in certain points of the abdominal cavity make it possible to confirm whether fluid is present (it is not possible to determine the nature of the fluid) (Fig. 7).

Another application of ultrasonography in dyspnea diagnostics may be the evaluation of lower limb veins for thrombosis. The presence of thrombi in the lumen of the veins increases the likelihood of diagnosing pulmonary embolism in the patient, also when typical changes are not present in the echocardiographic examination. The simplified protocol assess the susceptibility of veins to compression in two anatomical points of the lower limb venous system - the femoral vein in the area of the groin and the popliteal vein in the popliteal fossa $[18,25]$. If, as a result of compression, the vein collapses closing the lumen completely, it should be assumed that the 


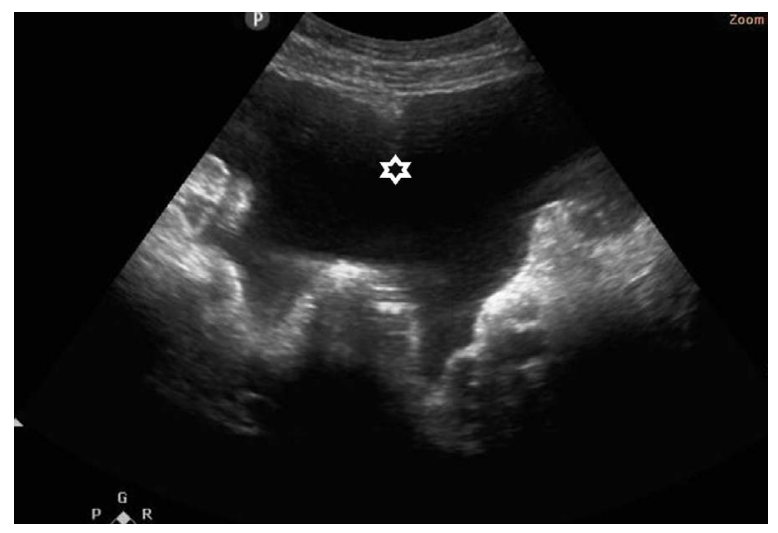

Figure 7. Evaluation of the abdominal cavity. Clinically significant amount of free fluid in the peritoneum $\left(^{*}\right)$ in suprapubic projection

vessel is unobstructed. If, as a result of compression, the lumen cannot be closed entirely, it should be assumed that there is a thrombus in its lumen. Apart from the evaluation of susceptibility, the presence of hyperechogenic, organised thrombus in lower limb venous vessels can also be visualised - verification of the image in the option of colour doppler can be helpful. Table 1 presents the diagnostic possibilities of ultrasonography in patients with dyspnea.

\section{Summary}

Bedside ultrasonography is a tool that is increasingly commonly used by doctors of many specialities. Thanks to advantages such as the possibility of performing the examination at the place of patient's stay, in conditions comfortable for the patient as well as non-invasiveness and repeatability of the method, it is useful for physicians working at home hospices. The examining physician can collect information on basic pathologies causing dyspnea and conduct differential diagnosis by placing the head in particular places. The examination is not targeted at detailed evaluation of organs and should be a screening examination. However, thanks to the gained knowledge, therapeutic management can be oriented without exposing the patient to the burdensome process of diagnostics conducted at the hospital. There may be situations where the conclusions from the POCUS examination will not indicate the cause of dyspnea. However, elimination of several common pathologies facilitates differential diagnosis [27].

Even though it is possible to develop basic imaging skills in point-of-care ultrasonography after several days of training, the technique requires constant practice of skills. Although the obtaining of the diagnostic image is usually quite obvious, clinical interpretation can be difficult at times. Constant practice of skills requires systematic trainings and work with multimedia tools [28].

\section{Declaration of conflict of interests}

The authors declare that there is no conflict of interest.

\section{Funding}

None declared.

No identifiable information about the patients is included in the manuscript.

Table 1. Ultrasound diagnostics of the causes of dyspnea in patients on palliative care

\begin{tabular}{|c|c|c|c|}
\hline Lungs and thorax & Heart & Abdominal cavity & Vessels \\
\hline $\begin{array}{l}\text { - Cardiogenic and non- } \\
\text { cardiogenic pulmonary } \\
\text { oedema } \\
\text { - Stasis in the pulmonary } \\
\text { circulation } \\
\text { - Pneumonia } \\
\text { — Fluid in pleural cavity } \\
\text { - Signs of pulmonary } \\
\text { microembolism } \\
\text { - Pneumothorax } \\
\text { - Atelectasis secondary to } \\
\text { cancer } \\
\text { - Neoplastic infiltration of } \\
\text { the chest }\end{array}$ & $\begin{array}{l}\text { - Global disorders of } \\
\text { kinesis } \\
\text { - Segmental disorders of } \\
\text { kinesis } \\
\text { - Pericardial effusion } \\
\text { - Indirect signs of pulmo- } \\
\text { nary embolism }\end{array}$ & $\begin{array}{l}\text { - Abdominal dropsy } \\
\text { - Gastroparesis } \\
\text { - Bowel obstruction } \\
\text { - Solid and fluid patholo- } \\
\text { gical masses }\end{array}$ & $\begin{array}{l}\text { - Evaluation of lower limb } \\
\text { thrombosis } \\
\text { - Evaluation of vessels } \\
\text { and flows in the supe- } \\
\text { rior vena cava syndrome }\end{array}$ \\
\hline
\end{tabular}




\section{References}

1. Andruszkiewicz P. Zastosowanie usg w resuscytacji krążeniowo-oddechowej i intensywnej terapii. Protokoły FEEL i FATE. Ultrasonografia. 2011; 45: 34-37.

2. Ciałkowska-Rysz A, Dzierżanowski T. Medycyna paliatywna. Termedia, Poznań 2019: 168-176.

3. Krajnik M, Malec-Milewska M. Chory na nowotwór-kompendium postępowania w wybranych sytuacjach klinicznych. Medical Education, Warszawa 2016.

4. Rogoza K, Kosiak W. Usefulness of lung ultrasound in diagnosing causes of exacerbation in patients with chronic dyspnea. Pneumonol Alergol Pol. 2016; 84(1): 38-46, doi: 10.5603/PiAP.a2015.0083, indexed in Pubmed: 26687671.

5. Volpicelli G, Elbarbary M, Blaivas $M$, et al. International Liaison Committee on Lung Ultrasound (ILC-LUS) for International Consensus Conference on Lung Ultrasound (ICC-LUS). International evidence-based recommendations for point-of-care lung ultrasound. Intensive Care Med. 2012; 38(4): 577-591, doi: 10.1007/s00134-012-2513-4, indexed in Pubmed: 22392031.

6. Lichtenstein DA, Mezière $\mathrm{G}$, Lascols $\mathrm{N}$, et al. Ultrasound diagnosis of occult pneumothorax. Crit Care Med. 2005; 33(6): 1231-1238, doi: 10.1097/01.ccm.0000164542.86954.b4, indexed in Pubmed: 15942336.

7. Lichtenstein DA. Lung ultrasound in the critically ill. Ann Intensive Care. 2014; 4(1): 1, doi: 10.1186/2110-5820-4-1, indexed in Pubmed: 24401163.

8. Lichtenstein $D$, Mezière G. The BLUE-points: three standardized points used in the BLUE-protocol for ultrasound assessment of the lung in acute respiratory failure. Critical Ultrasound Journal. 2011; 3(2): 109-110, doi: 10.1007/s13089-011-0066-3.

9. Lichtenstein D. Whole Body Ultrasonography in the Critically III. Springer. 2010, doi: 10.1007/978-3-642-05328-3.

10. Volpicelli G, Melniker LA, Cardinale L, et al. Lung ultrasound in diagnosing and monitoring pulmonary interstitial fluid. Radiol Med. 2013; 118(2): 196-205, doi: 10.1007/s11547012-0852-4, indexed in Pubmed: 22744356.

11. Lichtenstein DA, Lichtenstein D. Fluid administration limited by lung sonography: the place of lung ultrasound in assessment of acute circulatory failure (the FALLS-protocol). Expert Rev Respir Med. 2012; 6(2): 155-162, doi: 10.1586/ers.12.13, indexed in Pubmed: 22455488.

12. Lichtenstein $D$, Mézière $G$, Biderman $P$, et al. The comet-tail artifact. An ultrasound sign of alveolar-interstitial syndrome. Am J Respir Crit Care Med. 1997; 156(5): 1640-1646, doi: 10.1164/ajrccm.156.5.96-07096, indexed in Pubmed: 9372688.

13. Frassi F, Gargani L, Tesorio P, et al. Prognostic value of extravascular lung water assessed with ultrasound lung comets by chest sonography in patients with dyspnea and/or chest pain. J Card Fail. 2007; 13(10): 830-835, doi: 10.1016/j. cardfail.2007.07.003, indexed in Pubmed: 18068616.

14. Picano E, Frassi F, Agricola E, et al. Ultrasound lung comets: a clinically useful sign of extravascular lung water. J Am Soc Echocardiogr. 2006; 19(3): 356-363, doi: 10.1016/j. echo.2005.05.019, indexed in Pubmed: 16500505.

15. Buda N, Kosiak W, Radzikowska E, et al. Polish Committee on Lung Ultrasound (PC-LUS) for POLLUS-IM. Polish re- commendations for lung ultrasound in internal medicine (POLLUS-IM). J Ultrason. 2018; 18(74): 198-206, doi: 10.15557/JoU.2018.0030, indexed in Pubmed: 30451402.

16. Volpicelli G, Silva F, Radeos M. Real-time lung ultrasound for the diagnosis of alveolar consolidation and interstitial syndrome in the emergency department. Eur J Emerg Med. 2010; 17(2): 63-72, doi: 10.1097/mej.0b013e3283101685, indexed in Pubmed: 20945542.

17. Chung M, Goo J, Im JG, et al. Value of high-resolution ultrasound in detecting a pneumothorax. European Radiology. 2004; 15(5): 930-935, doi: 10.1007/s00330-004-2518-7.

18. Sobczyk D, Andruszkiewicz P, Andres J. Ultrasonografia w stanach zagrożenia życia i intensywnej terapii. Polska Rada Resuscytacji, Kraków 2012.

19. Nagdev A, Stone MB. Point-of-care ultrasound evaluation of pericardial effusions: does this patient have cardiac tamponade? Resuscitation. 2011; 82(6): 671-673, doi: 10.1016/j. resuscitation. 2011.02.004, indexed in Pubmed: 21397379.

20. Adler $Y$, Charron P, Imazio M, et al. ESC Scientific Document Group . 2015 ESC Guidelines for the diagnosis and management of pericardial diseases: The Task Force for the Diagnosis and Management of Pericardial Diseases of the European Society of Cardiology (ESC)Endorsed by: The European Association for Cardio-Thoracic Surgery (EACTS). Eur Heart J. 2015; 36(42): 2921-2964, doi: 10.1093/eurheartj/ehv318, indexed in Pubmed: 26320112.

21. Unlüer EE, Karagöz A, Akoğlu H, et al. Visual estimation of bedside echocardiographic ejection fraction by emergency physicians. West J Emerg Med. 2014; 15(2): 221-226, doi: 10.5811/westjem.2013.9.16185, indexed in Pubmed: 24672616.

22. Jones AE, Tayal VS, Sullivan DM, et al. Randomized, controlled trial of immediate versus delayed goal-directed ultrasound to identify the cause of nontraumatic hypotension in emergency department patients. Crit Care Med. 2004; 32(8): 1703-1708, doi: 10.1097/01.ccm.0000133017.34137.82, indexed in Pubmed: 15286547.

23. Pruszczyk P, Szulc M, Horszczaruk G, et al. Right ventricular infarction in a patient with acute pulmonary embolism and normal coronary arteries. Arch Intern Med. 2003; 163(9): 1110-1111, doi: 10.1001/archinte.163.9.1110, indexed in Pubmed: 12742812.

24. Kosiak W, Świetoń D, Czarniak P, et al. Pozasercowe ultrasonograficzne objawy niewydolności krążenia. Ultrasonografia. 2008; 32: 53-57.

25. Noble VE, Nelson B, Sutingco AN. Podręcznik ultrasonografii w medycynie ratunkowej $\mathrm{i}$ intensywnej terapii. Medipage, Warszawa 2010.

26. Lichtenstein DA, Malbrain ML. Lung ultrasound in the critically ill (LUCI): A translational discipline. Anaesthesiol Intensive Ther. 2017; 49(5): 430-436, doi: 10.5603/AIT, a2017.0063, indexed in Pubmed: 29151003.

27. Zanobetti M, Poggioni C, Pini R. Can chest ultrasonography replace standard chest radiography for evaluation of acute dyspnea in the ED? Chest. 2011; 139(5): 1140-1147, doi: 10.1378/chest.10-0435, indexed in Pubmed: 20947649.

28. Buda N, Kosiak W. Atlas przezklatkowej ultrasonografii płuc. AHU „DB” 2016. . https://lus.expert/. 


\section{Ultrasonograficzne możliwości diagnostyki przyczyn duszności}

\section{u chorych na nowotwory objętych opieką paliatywną}

Artykuł jest tłumaczeniem pracy: Cylwik J., Buda N. Possibilities of ultrasonography in diagnosing causes of dyspnea in palliative care cancer patients. Palliat. Med. Pract. 2020 tom 14, nr 3: 205-211. Należy cytować wersję pierwotną.

\section{Streszczenie}

Duszność jest często zgłaszana przez chorych na nowotwory, a ustalenie przyczyn tego objawu w warunkach hospicjum domowego może być trudne. Dzięki zastosowaniu przenośnego ultrasonografu lekarz podczas wizyty domowej może niejednokrotnie ustalić przyczynę duszności, co powoduje, że nie jest konieczne prowadzenie postępowania diagnostycznego w szpitalu. W artykule przedstawiono dwa przypadki chorych, u których wykorzystanie ultrasonografii w warunkach domowych okazało się przydatne w ustaleniu przyczyny duszności. U pierwszej z opisanych chorych rozpoznano w domu tamponadę osierdzia — w szpitalu wykonano nakłucie jamy osierdziowej, natomiast u drugiej pacjentki zarówno rozpoznano, jak i monitorowano zapalenie płuc leczone w warunkach domowych, stosując ultrasonografię.

Palliat Med Pract 2020; 14, 3: 212-218

Słowa kluczowe: ultrasonografia point-of-care, opieka paliatywna, duszność

\section{Wstęp}

Ultrasonografia typu point-of-care (POCUS) weszła do klinicznego użytku kilkanaście lat temu, głównie na oddziałach intensywnej terapii i szpitalnych oddziałach ratunkowych [1]. Opracowano wiele prostych algorytmów diagnostycznych, które ukierunkowane są na wykrywanie i różnicowanie podstawowych patologii, na przykład protokoły FAST (Focused Assessment with Sonography for Trauma), EFAST (Extended Focused Assessment with Sonography for Trauma), FEEL (Focused
Echocardiographic Evaluation in Life Support), FATE (Focus Assessment Transthoracic in Emergency), BLUE (Bedside Lung Ultrasound in Emergency), RUSH (Rapid Ultrasound in Shock and Hypotension). Z założenia badanie ma być wykonywane przez klinicystę bezpośrednio opiekującego się pacjentem, nie w pracowni diagnostycznej, ale przy łóżku chorego. Dostępność przenośnych, często zminiaturyzowanych, odpornych na uszkodzenia aparatów ultrasonograficznych umożliwia przeprowadzenie podstawowego badania ultrasonograficznego w dowolnym miejscu opieki.

\footnotetext{
Adres do korespondencji:

Jolanta Cylwik

Oddział Anestezjologii i Intensywnej Terapii, Mazowiecki Szpital Wojewódzki w Siedlcach

e-mail: jolacylwik@o2.pl
} 
Możliwość zastosowania ultrasonografii point-ofcare w grupie pacjentów objętych domową opieka hospicyjną wydaje się atrakcyjna. Bez konieczności transportu chorego do szpitala, w warunkach maksymalnie komfortowych dla pacjenta lekarz w czasie wizyty domowej jest $w$ stanie przeprowadzić wiarygodną diagnostykę różnicową wielu schorzeń i objawów, w tym duszności, ze szczególnym ukierunkowaniem badania na obecność przyczyn potencjalnie odwracalnych. Przedstawiono dwa przypadki chorych, u których wykorzystanie ultrasonografii w warunkach domowych okazało się przydatne $w$ ustaleniu rozpoznania przyczyny duszności

\section{Przypadek 1}

Chora lat 58 z rozpoznaniem nadciśnienia tętniczego, w trakcie radioterapii paliatywnej z powodu raka płuc z przerzutami do kości i ośrodkowego układu nerwowego (OUN). Od kilku dni pogarszające się samopoczucie. Mąż pacjentki poprosił o pilną wizytę lekarza hospicjum z powodu narastającej duszności — początkowo wysiłkowej, następnie spoczynkowej. W badaniu przedmiotowym pacjentka przytomna, Glasgow Coma Score (GCS) 15 punktów. Nasilona duszność spoczynkowa - około 40 oddechów na minutę, wzmożony wysiłek oddechowy, $\mathrm{SaO}_{2} 90 \%$. Osłuchowo obustronnie, przy podstawnie trzeszczenia. Ciśnienie krwi 85/60 mm Hg, czynność serca 140 na minutę. Symetryczne obrzęki podudzi. Temperatura ciała $36,4^{\circ} \mathrm{C}$, glikemia $100 \mathrm{mg} \%$. W ultrasonograficznej ocenie płuc, w partiach górnych obustronnie uwidoczniono artefakty linii A i zachowany objaw ślizgania. Dodatkowo obecne pojedyncze artefakty linii B. Przy podstawnie, obustronnie zlewające się w obraz "białego płuca” liczne artefakty linii B (ryc. 1).

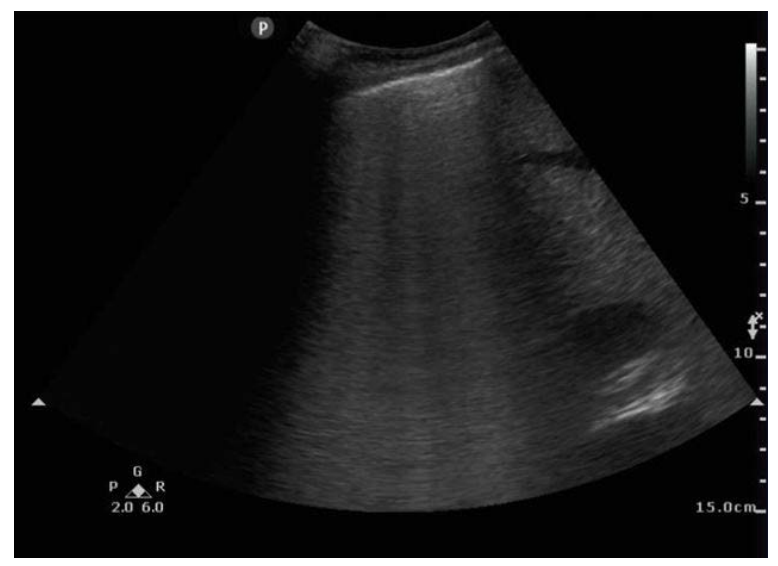

Rycina 1. Badania ultrasonograficzne płuc. Obraz zespołu śródmiąższowo-pęcherzykowego, „białe płuco". Zlewające się artefakty linii B. Artefakty linii A niewidoczne
Nie uwidoczniono konsolidacji zapalnych ani płynu w jamach opłucnowych. Kontynuowano badanie POCUS - ocena serca. W projekcji pod mostkowej uwidoczniono dużą objętość płynu w osierdziu, istotnego hemodynamicznie (ryc. 2).

Na podstawie wywiadu, badania przedmiotowego i badania ultrasonograficznego postawiono rozpoznanie - tamponada osierdzia. Pacjentka została w trybie pilnym skierowana na oddział kardiologii, gdzie wykonano nakłucie i odbarczono około $600 \mathrm{ml}$ krwistego płynu. Uzyskano całkowite ustąpienie duszności.

$U$ opisanej chorej rozszerzenie badania klinicznego o ultrasonografię umożliwiło przeprowadzenie diagnostyki różnicowej i ustalenie rozpoznania. Bez prostego, wykonanego w domu chorej badania ultrasonograficznego byłoby to niemożliwe. Podjęte leczenie było ukierunkowane na przyczynę objawu, dzięki czemu uzyskano ustąpienie duszności.

\section{Przypadek 2}

Chora lat $78 \mathrm{z}$ rozpoznaniem nowotworu jelita grubego z przerzutami do wątroby. Leczenie przyczynowe zakończone, od 4 tygodni chora była pod opieką hospicjum domowego. Pacjentka obciążona przewlekłą niewydolnością serca, nadciśnieniem tętniczym, chorobą niedokrwienną serca. Od kilku dni zgłasza pogorszanie samopoczucia, osłabienie, od poprzedniej doby gorączka do $39^{\circ} \mathrm{C}$. Od rana nasilenie duszności, rodzina wezwała lekarza hospicjum domowego.

W badaniu przedmiotowym, w spoczynku częstość oddechów około 18 na minutę, minimalny wysiłek powoduje nasilenie duszności, $\mathrm{SaO}_{2} 90 \%$. Osłuchowo po stronie lewej od kąta łopatki rozlane rzężenia. Układ krążenia wydolny - ciśnienie tętnicze krwi 150/90 mm Hg, czynność serca 100 na minutę. Temperatura ciała $38,4^{\circ} \mathrm{C}$, glikemia $180 \mathrm{mg} \%$.

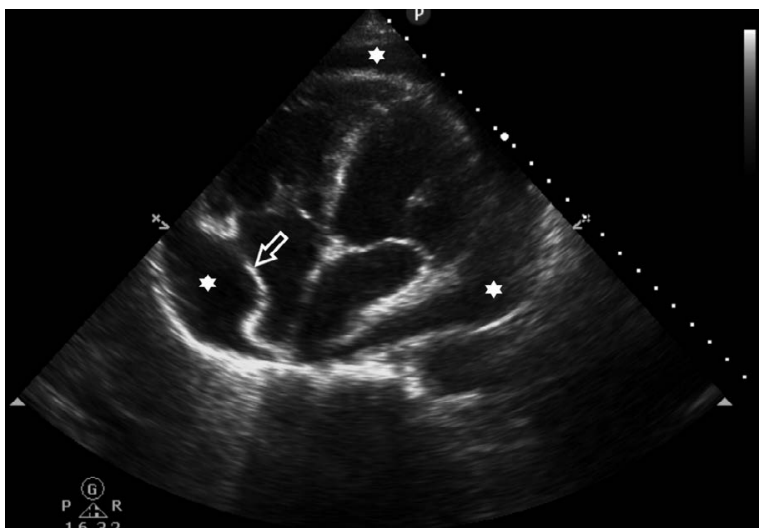

Rycina 2. Projekcja podmostkowa. Płyn w worku osierdziowym $\left(^{*}\right)$. Strzałką zaznaczono zapadającą się w czasie skurczu ścianę prawego przedsionka 


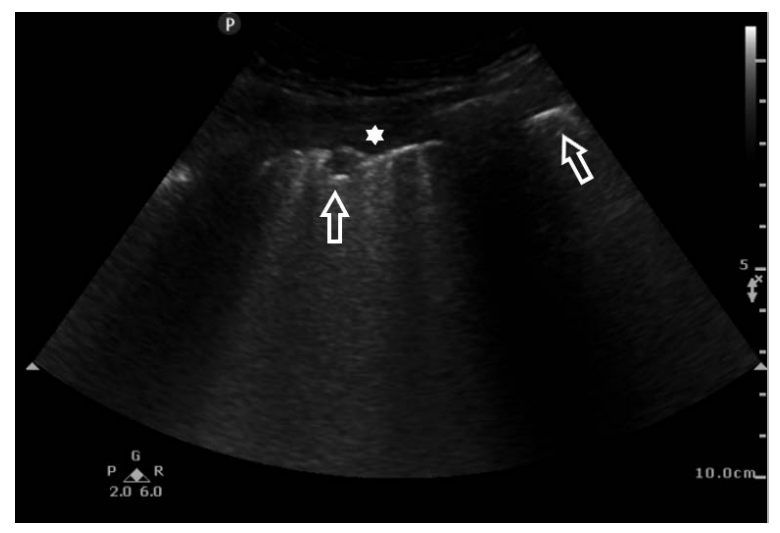

Rycina 3. Badanie ultrasonograficzne płuc - w polu dolnym płuca lewego liczne, drobne konsolidacje podopłucnowe $(\downarrow)$ oraz odcinkowo widoczna warstwa odczynowego płynu w opłucnej $\left({ }^{*}\right)$

Badanie ultrasonograficzne rozpoczęto od oceny miejsc, gdzie stwierdzono odchylenia w badaniu przedmiotowym - lewa połowa klatki piersiowej. W badaniu uwidoczniono w polu środkowym i dolnym liczne, drobne konsolidacje podopłucnowe i odcinkowo widoczną warstwę odczynowego płynu w opłucnej - obraz zapalenia płuc (ryc. 3).

Wstępne rozpoznanie zostało potwierdzone ultrasonograficznie w domu chorej. Wdrożono leczenie, którego skuteczność monitorowano kolejnymi badaniami ultrasonograficznymi.

\section{Dyskusja}

Duszność jest częstym objawem zgłaszanym przez chorych na nowotwory, występuje u 48-69\% chorych niezależnie od lokalizacji ogniska pierwotnego i u $80 \%$ chorych z rakiem płuca [2]. Duszność jest objawem złożonym - zgodnie z koncepcją total dyspnea na sposób i intensywność odczuwania duszności wpływają różnorodne czynniki, które obejmują komponent fizyczny, psychiczny, socjalny i duchowy [3]. Wśród przyczyn medycznych patologia może wynikać z obecności guza: zaburzenia drożności dróg oddechowych spowodowane obecnością masy patologicznej, nacieki nowotworu na tkankę płucną pierwotne i wtórne, zespół żyły głównej górnej, naciekanie opłucnej, wysięk w jamie opłucnej, wysięk w osierdziu, wodobrzusze. Kolejne przyczyny związane są z obecnością nowotworu - wyniszczenie, zatorowość płucna, zespoły paranowotworowe, zapalenie płuc. Na pojawienie się duszności mogą wpływać przyczyny związane ze skutkami leczenia przeciwnowotworowego zarówno chemicznego (włóknienie płuc, kwasochłonne zapalenie płuc, krwawienie do pęcherzyków), jak i radioterapii (popromienne zapalenie płuc, włóknienie płuc, zapalenie osierdzia). Niekiedy przyczyny duszności mogą wynikać z obecności i stopnia zaawansowania chorób współwystępujących: POChP, astma oskrzelowa, niewydolność serca, śródmiąższowe choroby płuc, choroby nerwowo-mięśniowe, otyłość, deformacje klatki piersiowej [2]. Część z powyższych przyczyn jest potencjalnie odwracalna.

\section{Ultrasonografia płuc point-of-care}

W czasie wizyty domowej u pacjenta z dusznością, objętego opieką hospicjum domowego, lekarz stara się ustalić przyczynę duszności, opierając się na dokładnie zebranym wywiadzie i badaniu fizykalnym. Z badań dodatkowych można zastosować pulsoksymetrię. Inne badania diagnostyczne - laboratoryjne i klasyczne obrazowe często nie są z oczywistych powodów możliwe do wykonania w warunkach domowych. Pamiętając, że u chorego na zaawansowany nowotwór zwykle współistnieje klika przyczyn duszności, z których co najmniej jedna zazwyczaj jest odwracalna [3], możliwości diagnostyczne, które daje podstawowe badanie ultrasonograficzne, mogą mieć istotną wartość.

Diagnostyka obrazowa podczas wizyty domowej spełnia podstawowe założenia ultrasonografii poin$t$-of-care. Do wykonania badania ultrasonograficznego w warunkach domowych całkowicie wystarczy prosty aparat ultrasonograficzny o podstawowych funkcjach. Istnieje tendencja do takiego konstruowania protokołów badań, aby całą podstawową diagnostykę można było wykonać za pomocą jednej głowicy — najczęściej typu convex (standardowa głowica do oceny jamy brzusznej) o częstotliwości 3,5-5,0 MHz [4]. Głowicą tą można ocenić zarówno narządy klatki piersiowej (serce, płuca), jak i jamy brzusznej. Jeżeli lekarz jest w posiadaniu dodatkowej głowicy liniowej, badanie można rozszerzyć o ocenę naczyń kończyn dolnych i wykorzystać głowicę do szczegółowego badania płuc. Badanie ultrasonograficzne ukierunkowane na wykrycie przyczyny duszności można wykonać w zasadzie w każdej pozycji pacjenta - na leżąco, siedząco czy stojąco, w zależności od możliwości i potrzeb chorego.

Uznanym na świecie algorytmem diagnostycznym duszności jest protokół BLUE (Bedside Lung Ultrasonography in Emergency) różnicujący na podstawie badania ultrasonograficznego podstawowe patologie płucne. Jego znajomość jest obowiązkowa dla lekarzy rozpoczynających pracę zgodną z POCUS. W niniejszym opracowaniu przedstawiono głównie założenia i możliwości diagnostyczne badania ultrasonograficznego w domu chorego, dlatego schemat ten nie będzie szczegółowo omawiany.

Diagnostyka ultrasonograficzna płuc rozwijała się etapami [4], w 2012 roku ukazał się konsensus z zakresu ultrasonografii płuc [5]. Istotną zaletą oceny 


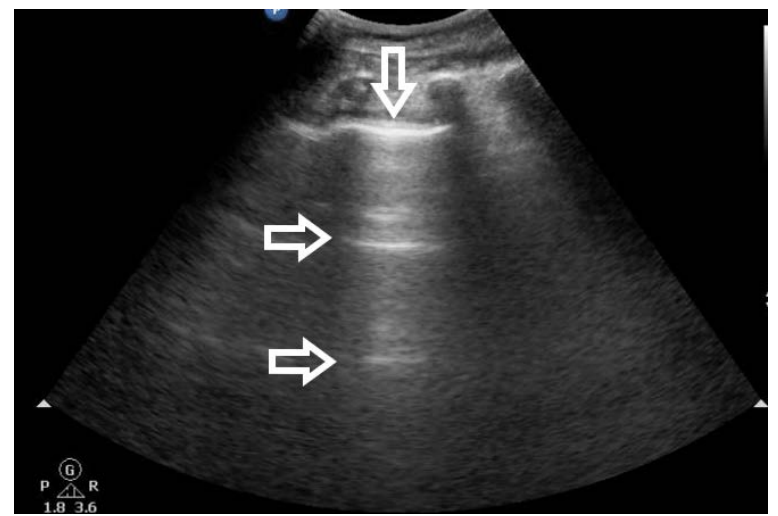

Rycina 4. Prawidłowy obraz ultrasonograficzny płuc. Linia opłucnej $(\downarrow)$, układ artefaktów linii $A(\rightarrow)$

płuc jest łatwość uzyskania dobrego diagnostycznie obrazu — trudniejsza jest interpretacja uzyskanych skanów. Metoda taka oparta jest na ocenie artefaktów fizycznych, które powstają na granicy opłucnej i miąższu płuca (powietrze obecne w pęcherzykach płucnych uniemożliwia rozchodzenie się w głąb wiązki ultradźwięków). Oczywistym jest więc, że możliwa jest wizualizacja jedynie patologii, które mają bezpośredni kontakt z opłucną — jeżeli zmiana patologiczna zlokalizowana jest w głębszych warstwach, powietrze zawarte między nią a ścianą klatki piersiowej uniemożliwi jej zobrazowanie [6].

W medycynie paliatywnej ultrasonografię cechują liczne zalety, takie jak możliwość wykonania w domu pacjenta, brak konieczności specjalnego ułożenia chorych, nie wywoływanie bólu, brak emisji promieniowania jonizującego i możliwość powtarzania badania. Ponadto, ultrasonografia zapewnia możliwość szybkiego różnicowania pomiędzy zmianami zapalnymi związanymi z progresją choroby nowotworowej, obrzękiem płuc i obecnością płynu w jamie opłucnej [7].

Badanie wykonuje się, przesuwając głowicę ustawioną w poprzek międzyżebrzy po przedniej, bocznej i tylnej powierzchni klatki piersiowej. Można wykonać badanie orientacyjne, oceniając po 3 symetryczne punkty po obydwu stronach klatki piersiowej na przedniej i na tylnej powierzchni albo dokonać szczegółowej oceny całych płuc [8].

Artefaktem występującym w obrazie prawidłowego płuca są linie $A$ - hiperechogenne, równoległe do opłucnej linie, powtarzające się w obrazie ultrasonograficznym regularnie, w odstępach zgodnych z odległością pomiędzy powierzchnią ściany klatki piersiowej a linią opłucnej (artefakt rewerberacji). Jeżeli artefakt linii A współwystępuje z objawem ślizgania opłucnej (widoczny względem siebie ruch blaszek opłucnej zgodny z rytmem oddechowym), obraz świadczy o prawidłowo powietrznym płucu [7] (ryc. 4).

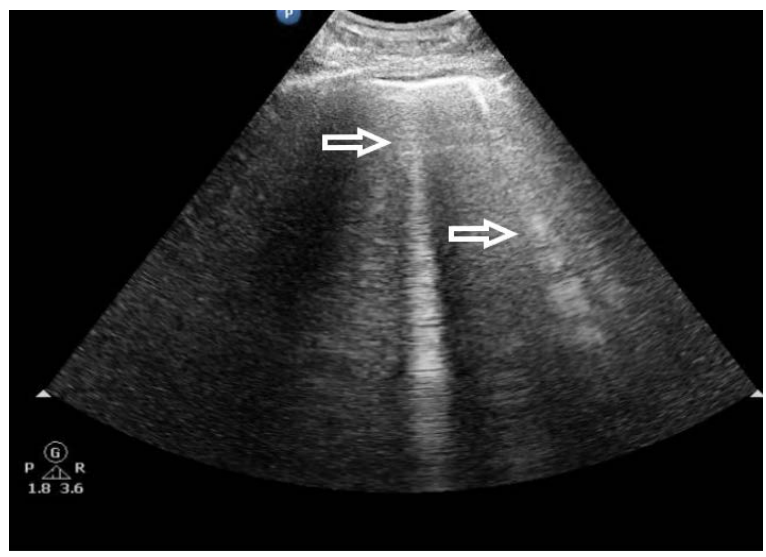

Rycina 5. Przezklatkowa ocena płuc. Obecność licznych linii B $(\rightarrow)$ świadczy o zespole śródmiąższowo-pęcherzykowym

W przypadku niewydolności serca dochodzi do nadmiernego gromadzenia płynu, początkowo międzypłacikowo, a wraz ze wzrostem jego ilości tworzą się zespoły śródmiąższowo-pęcherzykowe. Obecność płynu pozanaczyniowego powoduje wystąpienie w obrazowaniu ultrasonograficznym charakterystycznych artefaktów linii B - pionowych, hiperechogennych linii rozpoczynających się na linii opłucnej, biegnących do dolnego brzegu ekranu, niezależnie od ustawienia głębokości obrazowania (ryc. 5).

Obecność do dwóch linii B w pojedynczym oknie diagnostycznym jest uznawana za normę, zwłaszcza w tylno-dolnych partiach płuc. Jeżeli uwidocznione zostaną 3 lub więcej takich linii, świadczy to o patologii [9]. Liczba artefaktów linii B dobrze koreluje ze stanem klinicznym pacjenta i nasileniem niewydolności serca zgodnie z klasyfikacją NYHA [10-14]. Obraz ultrasonograficzny potwierdzający obecność zespołu śródmiąższowego uznano za jednoznaczny i upoważniający do odróżnienia kardiologicznego obrzęku płuc od zaostrzenia POChP czy innej patologii $[5,13]$.

Oprócz zmian o typie obrzękowych, ultrasonografia płuc zapewnia możliwość identyfikacji obecności konsolidacji zapalnych. Obszar objęty procesem zapalnym ulega skonsolidowaniu, w efekcie czego pojawia się objaw „zwątrobienia” płuca. Echogenność tkanki płucnej staje się porównywalna z echogennością wątroby. Pojawia się "shred sign”, czyli linia granicy płuca zamiast gładkiej, staje się postrzępiona, nierówna, zatarta. Dodatkowo widoczny jest bronchogram powietrzny (powietrze w drzewie oskrzelowym w obrębie konsolidacji) i bronchogram płynowy $[15,16]$ (ryc. 6).

Oprócz zmian zapalnych czy związanych z niewydolnością serca przyczyną duszności u chorych objętych opieką paliatywną może być płyn w opłucnej. Jego umiejscowienie, tempo narastania i związane $z$ tym na- 


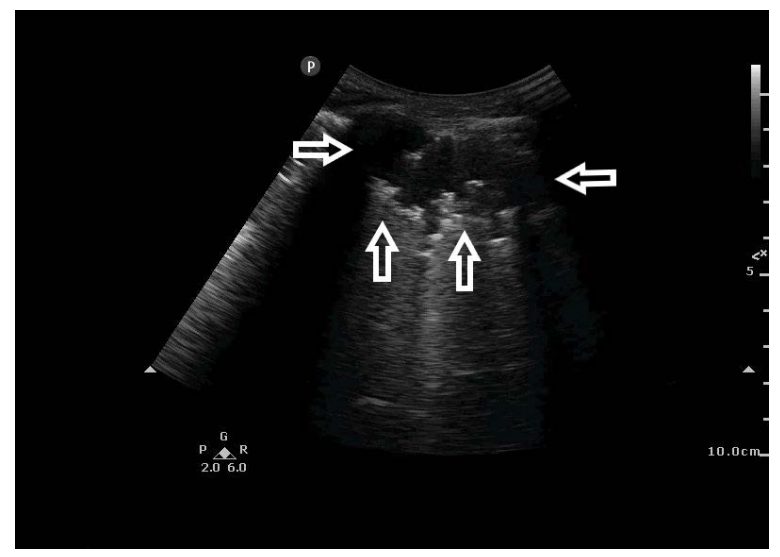

Rycina 6. Badanie ultrasonograficzne płuc. Podopłucnowa konsolidacja zapalna (otoczona strzałkami). Widoczny objaw zwątrobienia, „shred sing" i bronchogram płynowy

silenie objawów jest bardzo różne, dlatego proste i czułe badanie, jakim jest ultrasonografia, może być bardzo pomocne w określeniu lokalizacji, ocenie objętości płynu, a zwłaszcza ustalenie miejsca nakłucia jamy opłucnej.

Nakłucie jamy opłucnej jest procedurą obarczoną ryzykiem powstania odmy opłucnowej. Ultrasonograficznie, z bardzo dużą swoistością i czułością, można wykryć to powikłanie: zniesienie objawu ślizgania opłucnej, obecność artefaktu linii A, całkowity brak linii $\mathrm{B}$, obecność lung point i dodatkowo $\mathrm{w}$ opcji M-mode objaw kodu paskowego [17].

\section{Ultrasonografia serca point-of-care}

Po wykonaniu oceny ultrasonograficznej płuc, niezależnie od wyniku tej oceny, to znaczy, czy znaleziono potencjalną przyczynę duszności czy nie, kolejnym krokiem w ocenie powinna być podstawowa ocena serca. Patologie spowodowane chorobą serca, osierdzia czy krążenia płucnego mogą być przyczyną nasilonej duszności u pacjenta objętego opieką paliatywną. Badanie powinno być ukierunkowane na zidentyfikowanie kluczowych patologii, a przeprowadzający badanie powinien starać się odpowiedzieć na następujące pytania [18]:

1. Czy w worku osierdziowym znajduje się płyn mogący powodować tamponadę?

2. Jaka jest globalna kurczliwość mięśnia sercowego?

3. Czy prawidłowy jest stosunek wielkości lewej komory serca do prawej komory serca (możliwość masywnej zatorowości płucnej)?

Do wykonania podstawowej oceny zazwyczaj wystarczy klasyczna projekcja podmostkowa z wykorzystaniem wątroby jako okna akustycznego. Głowicę typu convex należy przyłożyć poniżej wyrostka mieczykowatego pod katem około $15^{\circ} \mathrm{w}$ stosunku do przedniej ściany klatki piersiowej. Projekcja pozwala dobrze uwidocznić zarówno osierdzie, jak i prawą komorę. Nawet przy trudnych warunkach technicznych badania można ocenić kluczowe elementy diagnostyczne.

Pierwszym elementem, na który należy zwrócić uwagę, jest obecność płynu separującego blaszki osierdzia. Jeżeli płyn jest obecny, a dodatkowo wpływa on na hemodynamikę niskociśnieniowej prawej komory i prawego przedsionka, jako przyczynę duszności można przyjąć tamponadę [19, 20].

Oszacowanie globalnej kurczliwości mięśnia sercowego powinno obejmować ocenę skracania ścian, lewej i prawej komory oraz kurczliwości przegrody międzykomorowej. Ocenę frakcji dokonuje się w sposób szacunkowy, określając jako dobrą lub niską [21]. Jeżeli stwierdzono całościowo słabą kurczliwość z towarzyszącym poszerzeniem jam serca, można przypuszczać, że u danego pacjenta występuje zespół małego rzutu i wywołana nim duszność. Jeżeli dodatkowo w ocenie płuc obrazowane są liczne linie $B$, rozpoznanie jest pewne.

Jak już wspomniano, w podstawowym badaniu echokardiograficznym należy określić proporcje wielkości lewej komory do prawej. W warunkach prawidłowych stosunek ten wynosi 1:0,6 [22]. Niezależnie od przyczyny, wzrost ciśnienia w krążeniu płucnym powoduje poszerzenie jamy prawej komory i przedsionka. Klasycznym przykładem jest zatorowość płucna, która jest częstym powikłaniem chorób nowotworowych. W przypadku ostrej, masywnej zatorowości poszerzenie światła prawej komory będzie znaczne i będzie dominować wielkością nad lewą komorą. W nadciśnieniu płucnym można zaobserwować również patologiczny ruch przegrody międzykomorowej zarówno w rozkurczu, jak i skurczu serca. Cechą nadciśnienia płucnego jest również tworzenie koniuszka serca przez prawą, a nie jak w warunkach prawidłowych, lewą komorę serca (objaw McConnella ma wysoką dodatnią wartość predykcyjną dla zatorowości płucnej) [23]. Wnioski wypływające z odpowiedzi na powyższe 3 najważniejsze pytania mogą zdecydowanie wpłynąć na dalsze ukierunkowanie leczenia pacjenta z dusznością.

Omawiając możliwości szybkiej, przyłóżkowej diagnostyki ultrasonograficznej u pacjentów z dusznością, należy podkreślić, że badanie pozwala na możliwość identyfikacji patologii poza klatką piersiową, które mogą powodować lub nasilać duszność [24]. Przykładem diagnostyki różnicowej jest ocena obecności wolnego płynu w jamie brzusznej, co stanowi częsty objaw u chorych na nowotwory. Jeżeli wodobrzusze jest masywne i powoduje zespół nadciśnienia śródbrzusznego może być przyczyną duszności. Ocena płynu w otrzewnej jest dość prosta. Jako pomocny może być protokół FAST - 4 przyłożenia głowicy w określonych punktach jamy brzusznej umożliwiają 


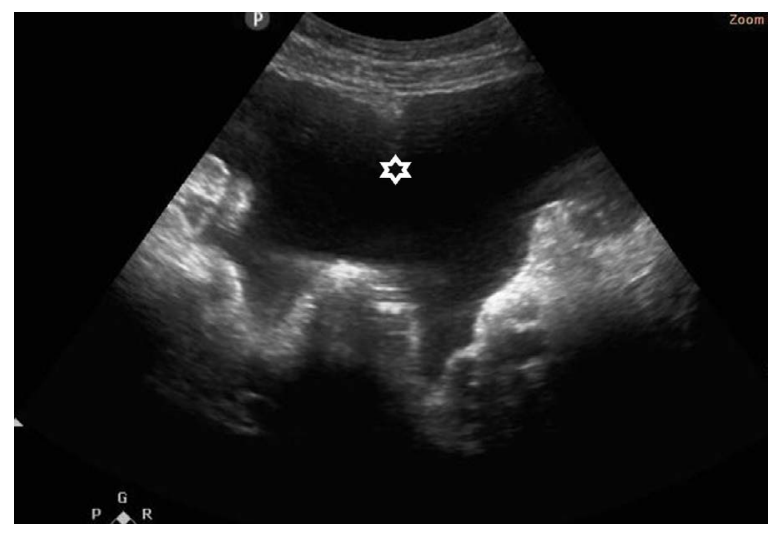

Rycina 7. Ocena jamy brzusznej. Klinicznie istotna objętość wolnego płynu w otrzewnej ${ }^{*}$ ) w projekcji nadłonowej

odpowiedź na pytanie, czy płyn jest obecny (nie jest możliwe określenie charakteru tego płynu) (ryc. 7).

Kolejnym zastosowaniem ultrasonografii w diagnostyce duszności może być ocena żył kończyn dolnych pod kątem zakrzepicy. Obecność skrzeplin w świetle żył zwiększa prawdopodobieństwo rozpoznania zatorowości płucnej u chorego, także przy braku typowych zmian w podstawowej ocenie echokardiograficznej. W uproszczonym protokole oceniana jest podatność żył na ucisk $w$ dwóch anatomicznych punktach układu żylnego kończyny dolnej — żyły udowej w okolicy pachwiny i żyły podkolanowej w dole podkolanowym $[18,25]$. Jeżeli w wyniku ucisku żyła zapada się zamykając całkowicie światło, należy przyjąć, że naczynie jest drożne. Jeżeli w wyniku ucisku nie można uzyskać całkowitego zamknięcia światła, przyjmuje się, że w jej świetle jest skrzeplina. Oprócz oceny podatności uwidocznić można również obecność hiperechogennej, zorganizowanej skrzepliny w naczyniach żylnych — pomocna może być weryfikacja obrazu w opcji kolorowego Dopplera. W tabeli 1 przedstawiono możliwości diagnostyczne ultrasonografii u chorych z dusznością.

\section{Podsumowanie}

Przyłóżkowa ultrasonografia jest coraz powszechniej stosowanym narzędziem przez lekarzy wielu specjalizacji [26]. Dzięki zaletom, takim jak możliwość wykonania badania w miejscu pobytu chorego, w komfortowych warunkach dla pacjenta, bezpieczeństwa, nieinwazyjności i powtarzalności, jest przydatna dla lekarzy pracujących w hospicjach domowych. Dzięki określonym przyłożeniom głowicy badający lekarz jest w stanie zebrać informacje dotyczące podstawowych patologii, które mogą powodować duszność i przeprowadzić diagnostykę różnicową. Badanie nie ma na celu szczegółowej oceny narządowej — powinno mieć charakter screeningu. Jednak dzięki uzyskaniu istotnej wiedzy można ukierunkować postępowanie terapeutyczne, bez narażania pacjenta na uciążliwą diagnostykę szpitalną. Mogą zdarzyć się sytuacje, kiedy wnioski z badania POCUS nie dadzą odpowiedzi na pytanie o przyczynę duszności, jednak wyeliminowanie kilku częstych patologii ułatwia diagnostykę różnicową [27].

Uzyskanie podstawowych umiejętności obrazowania w ultrasonografii typu point-of-care jest możliwe po kilkudniowym szkoleniu, wymaga jednak stałego ćwiczenia umiejętności. Chociaż uzyskanie diagnostycznego obrazu zazwyczaj jest dość oczywiste, to kliniczna interpretacja niekiedy może być trudna. Do stałego podnoszenia umiejętności niezbędne są systematyczne szkolenia i praca z narzędziami multimedialnymi [28].

\section{Deklaracja konfliktu interesów}

Autorzy oświadczają, że nie występuje konflikt interesów.

\section{Finansowanie}

To badanie nie zostało sfinansowane

Manuskrypt nie zawiera informacji, które mogłyby umożliwić identyfikację pacjentek.

Tabela 1. Diagnostyka ultrasonograficzna przyczyn duszności u chorych w opiece paliatywnej

\begin{tabular}{|c|c|c|c|}
\hline Płuca i klatka piersiowa & Serce & Jama brzuszna & Naczynia \\
\hline $\begin{array}{l}\text { - Kardiogenny i niekardio- } \\
\text { genny obrzęk płuc } \\
\text { - Zastój w krążeniu płu- } \\
\text { cnym } \\
\text { - Zapalenie płuc } \\
\text { - Płyn w jamie opłucnej } \\
\text { - Cechy mikrozatorowości } \\
\text { płucnej } \\
\text { - Odma opłucnej } \\
\text { - Niedodma wtórna do } \\
\text { choroby nowotworowej } \\
\text { - Naciek nowotworowy } \\
\text { klatki piersiowej }\end{array}$ & $\begin{array}{l}\text { - Globalne zaburzenia } \\
\text { kinezy } \\
\text { - Odcinkowe zaburzenia } \\
\text { kinezy } \\
\text { - Płyn w osierdziu } \\
\text { - Pośrednie cechy zatoro- } \\
\text { wości płucnej }\end{array}$ & $\begin{array}{l}\text { - Wodobrzusze } \\
\text { - Gastropareza } \\
\text { - Niedrożność jelit } \\
\text { - Lite i płynowe masy } \\
\text { patologiczne }\end{array}$ & $\begin{array}{l}\text { - Ocena zakrzepicy żylnej } \\
\text { kończyn } \\
\text { - Ocena naczyń i prze- } \\
\text { pływów w zespole żyły } \\
\text { głównej górnej }\end{array}$ \\
\hline
\end{tabular}




\section{References}

1. Andruszkiewicz P. Zastosowanie usg w resuscytacji krążeniowo-oddechowej i intensywnej terapii. Protokoły FEEL i FATE. Ultrasonografia. 2011; 45: 34-37.

2. Ciałkowska-Rysz A, Dzierżanowski T. Medycyna paliatywna. Termedia, Poznań 2019: 168-176.

3. Krajnik M, Malec-Milewska M. Chory na nowotwór-kompendium postępowania w wybranych sytuacjach klinicznych. Medical Education, Warszawa 2016.

4. Rogoza K, Kosiak W. Usefulness of lung ultrasound in diagnosing causes of exacerbation in patients with chronic dyspnea. Pneumonol Alergol Pol. 2016; 84(1): 38-46, doi: 10.5603/PiAP.a2015.0083, indexed in Pubmed: 26687671.

5. Volpicelli G, Elbarbary M, Blaivas $M$, et al. International Liaison Committee on Lung Ultrasound (ILC-LUS) for International Consensus Conference on Lung Ultrasound (ICC-LUS). International evidence-based recommendations for point-of-care lung ultrasound. Intensive Care Med. 2012; 38(4): 577-591, doi: 10.1007/s00134-012-2513-4, indexed in Pubmed: 22392031.

6. Lichtenstein DA, Mezière $\mathrm{G}$, Lascols $\mathrm{N}$, et al. Ultrasound diagnosis of occult pneumothorax. Crit Care Med. 2005; 33(6): 1231-1238, doi: 10.1097/01.ccm.0000164542.86954.b4, indexed in Pubmed: 15942336.

7. Lichtenstein DA. Lung ultrasound in the critically ill. Ann Intensive Care. 2014; 4(1): 1, doi: 10.1186/2110-5820-4-1, indexed in Pubmed: 24401163.

8. Lichtenstein $D$, Mezière G. The BLUE-points: three standardized points used in the BLUE-protocol for ultrasound assessment of the lung in acute respiratory failure. Critical Ultrasound Journal. 2011; 3(2): 109-110, doi: 10.1007/s13089-011-0066-3.

9. Lichtenstein D. Whole Body Ultrasonography in the Critically III. Springer. 2010, doi: 10.1007/978-3-642-05328-3.

10. Volpicelli G, Melniker LA, Cardinale L, et al. Lung ultrasound in diagnosing and monitoring pulmonary interstitial fluid. Radiol Med. 2013; 118(2): 196-205, doi: 10.1007/s11547012-0852-4, indexed in Pubmed: 22744356.

11. Lichtenstein DA, Lichtenstein D. Fluid administration limited by lung sonography: the place of lung ultrasound in assessment of acute circulatory failure (the FALLS-protocol). Expert Rev Respir Med. 2012; 6(2): 155-162, doi: 10.1586/ers.12.13, indexed in Pubmed: 22455488.

12. Lichtenstein $D$, Mézière $G$, Biderman $P$, et al. The comet-tail artifact. An ultrasound sign of alveolar-interstitial syndrome. Am J Respir Crit Care Med. 1997; 156(5): 1640-1646, doi: 10.1164/ajrccm.156.5.96-07096, indexed in Pubmed: 9372688.

13. Frassi F, Gargani L, Tesorio P, et al. Prognostic value of extravascular lung water assessed with ultrasound lung comets by chest sonography in patients with dyspnea and/or chest pain. J Card Fail. 2007; 13(10): 830-835, doi: 10.1016/j. cardfail.2007.07.003, indexed in Pubmed: 18068616.

14. Picano E, Frassi F, Agricola E, et al. Ultrasound lung comets: a clinically useful sign of extravascular lung water. J Am Soc Echocardiogr. 2006; 19(3): 356-363, doi: 10.1016/j. echo.2005.05.019, indexed in Pubmed: 16500505.

15. Buda N, Kosiak W, Radzikowska E, et al. Polish Committee on Lung Ultrasound (PC-LUS) for POLLUS-IM. Polish re- commendations for lung ultrasound in internal medicine (POLLUS-IM). J Ultrason. 2018; 18(74): 198-206, doi: 10.15557/JoU.2018.0030, indexed in Pubmed: 30451402.

16. Volpicelli G, Silva F, Radeos M. Real-time lung ultrasound for the diagnosis of alveolar consolidation and interstitial syndrome in the emergency department. Eur J Emerg Med. 2010; 17(2): 63-72, doi: 10.1097/mej.0b013e3283101685, indexed in Pubmed: 20945542.

17. Chung $\mathrm{M}, \mathrm{Goo} J, \mathrm{Im} J \mathrm{G}$, et al. Value of high-resolution ultrasound in detecting a pneumothorax. European Radiology. 2004; 15(5): 930-935, doi: 10.1007/s00330-004-2518-7.

18. Sobczyk D, Andruszkiewicz P, Andres J. Ultrasonografia w stanach zagrożenia życia i intensywnej terapii. Polska Rada Resuscytacji, Kraków 2012.

19. Nagdev A, Stone MB. Point-of-care ultrasound evaluation of pericardial effusions: does this patient have cardiac tamponade? Resuscitation. 2011; 82(6): 671-673, doi: 10.1016/j. resuscitation. 2011.02.004, indexed in Pubmed: 21397379.

20. Adler $Y$, Charron P, Imazio M, et al. ESC Scientific Document Group . 2015 ESC Guidelines for the diagnosis and management of pericardial diseases: The Task Force for the Diagnosis and Management of Pericardial Diseases of the European Society of Cardiology (ESC)Endorsed by: The European Association for Cardio-Thoracic Surgery (EACTS). Eur Heart J. 2015; 36(42): 2921-2964, doi: 10.1093/eurheartj/ehv318, indexed in Pubmed: 26320112.

21. Unlüer EE, Karagöz A, Akoğlu H, et al. Visual estimation of bedside echocardiographic ejection fraction by emergency physicians. West J Emerg Med. 2014; 15(2): 221-226, doi: 10.5811/westjem.2013.9.16185, indexed in Pubmed: 24672616.

22. Jones AE, Tayal VS, Sullivan DM, et al. Randomized, controlled trial of immediate versus delayed goal-directed ultrasound to identify the cause of nontraumatic hypotension in emergency department patients. Crit Care Med. 2004; 32(8): 1703-1708, doi: 10.1097/01.ccm.0000133017.34137.82, indexed in Pubmed: 15286547.

23. Pruszczyk P, Szulc M, Horszczaruk G, et al. Right ventricular infarction in a patient with acute pulmonary embolism and normal coronary arteries. Arch Intern Med. 2003; 163(9): 1110-1111, doi: 10.1001/archinte.163.9.1110, indexed in Pubmed: 12742812.

24. Kosiak W, Świetoń D, Czarniak P, et al. Pozasercowe ultrasonograficzne objawy niewydolności krążenia. Ultrasonografia. 2008; 32: 53-57.

25. Noble VE, Nelson B, Sutingco AN. Podręcznik ultrasonografii w medycynie ratunkowej $\mathrm{i}$ intensywnej terapii. Medipage, Warszawa 2010.

26. Lichtenstein DA, Malbrain ML. Lung ultrasound in the critically ill (LUCI): A translational discipline. Anaesthesiol Intensive Ther. 2017; 49(5): 430-436, doi: 10.5603/AIT. a2017.0063, indexed in Pubmed: 29151003.

27. Zanobetti M, Poggioni C, Pini R. Can chest ultrasonography replace standard chest radiography for evaluation of acute dyspnea in the ED? Chest. 2011; 139(5): 1140-1147, doi: 10.1378/chest.10-0435, indexed in Pubmed: 20947649.

28. Buda N, Kosiak W. Atlas przezklatkowej ultrasonografii płuc. AHU „DB” 2016. . https://lus.expert/. 